\title{
ANALISIS PENGGUNAAN MODEL POE2WE UNTUK REMEDIASI MISKONSEPSI PADA MATERI SUHU DAN KALOR
}

\author{
${ }^{1}$ Rhifa Diana, ${ }^{2}$ Nana \\ Pendidikan Fisika \\ Fakultas Keguruan dan Ilmu Pendidikan, Universitas Siliwangi \\ Tasikmalaya, Jawa Barat, Indonesia 46115
}

Email: rhifadiana15@gmail.com

\begin{abstract}
Abstrak. Salah satu permasalahan dalam mata pelajaran Fisika adalah miskonsepsi. Miskonsepsi terjadi karena kesalahpahaman peserta didik dalam memahami konsep dari suatu materi salah satunya materi suhu dan kalor. Penulisan ini bertjuan untuk mendeskripsikan penggunaan model POE2WE untuk remediasi miskonsepsi pada materi suhu dan kalor. Metode yang digunakan dalam penulisan ini adalah studi literature (studi pustaka) dengan mengkaji beberapa sumber literature kemudian dianalisis dan ditarik menjadi sebuah kesimpulan. Hasil penulisan menunjukkan bahwa model POE2WE dapat digunakan sebagai upaya remediasi miskonsepsi pada materi suhu dan kalor. Dalam pembelajaran aktivitas guru dan siswa sangat berpengaruh dalam meminimalisir terjadi miskonsepsi pada suatu materi.
\end{abstract}

Kata Kunci: Model POE2WE, Miskonsepsi, Suhu dan Kalor

Abstract: One of the problems in Physics subjects is misconceptions. Misconceptions occur due to misunderstandings of students in understanding the concept of a material, one of which is temperature and heat. This paper aims to describe the use of the POE2WE model for the remediation of misconceptions on the matter of temperature and heat. The method used in this paper is a literature study (library study) by reviewing several literature sources then analyzed and drawn into a conclusion. The results of the writing show that the POE2WE model can be used as an effort to remediate misconceptions on the material of temperature and heat. In learning the activities of teachers and students are very influential in minimizing misconceptions in a material.

Keywords: POE2WE Model, Misconceptions, Temperature and Heat

\section{PENDAHULUAN}

Fisika merupakan salah satu mata pelajaran yang dipelajari peserta didik pada jenjang Sekolah Menengah Atas (SMA/MA). Sebagian besar peserta didik menganggap bahwa Fisika merupakan salah satu mata pelajaran yang sulit untuk dipahami. Hal tersebut dikarenakan terdapat pemahaman konsep dalam teori Fisika dan kumpulan rumus yang akhirnya mengakibatkan peserta didik kesulitan untuk memahami materi (R. Lebdiana, 2015). 
Dari kesalahan dan kesulitan peserta didik dalam memahami konsep materi yang lebih cenderung menghafal suatu materi akan dapat mempengaruhi efektivitas proses pembelajaran dan berdampak negative terhadap hasil belajar peserta didik (Wahyuningsih. Tri, 2013). Permasalahan dari kesalahan dan kesulitan tersebut timbul akibat adanya miskonsepsi pada diri peserta didik.

Miskonsepsi merupakan kesenjangan pemahaman konsep yang dimiliki siswa dengan konsep yang dimiliki oleh para ahli. Miskonsepsi ini terjadi pada mata pelajaran yang memiliki konsep abstrak, salah satunya fisika. Materi dalam fisika yang sering menimbulkan miskonsepsi pada peserta didik salah satunya yaitu suhu dan kalor (Nhurzahra. dkk, 2015). Pada materi suhu dan kalor kebanyakan peserta didik menjelaskan kalor itu bukan sebagai energi, namun sebagai zat (Fitriah. Lutfiyanti, 2017).

Miskonsepsi disebabkan oleh bermacam-macam hal. Secara umum dapat disebabkan oleh siswa sendiri, guru yang mengajar, konteks pembelajaran, cara mengajar dan buku teks. Faktor yang dapat menimbulkan miskonsepsi secara umum yaitu disebabkan oleh siswa sendiri, guru yang mengajar, konteks pembelajaran dan penggunaan buku teks dalam mengajar (Nana, 2020).
Diterapkannya penggunaaan model POE2WE Pada pembelajaran Fisika SMA diharapkan dapat meminimalisir miskonsepsi siswa terhadap materi pembelajaran. Oleh karena itu diperlukannya membahasa bagaimana penggunaan model POE2WE untuk remediasi miskonsepsi siswa pada materi suhu dan kalor.

\section{METODE PENELITIAN}

Dalam penulisan ini metode yang digunakan yaitu metode studi literature (studi pustaka) dengan cara mengumpulkan berbagai sumber informasi seperti hasil penelitian penelitian sebelumnya dan jurnal atau artikel yang berkaitan dengan masalah yang akan dipecahkan. Kemudian data yang diperoleh dianalisis dan disajikan dalam bentuk hasil dan pembahasan serta dibuat kesimpulan.

\section{HASIL DAN PEMBAHASAN Identifikasi Miskonsepsi Suhu dan Kalor}

1. Miskonsespsi Siswa tentang Konsep Suhu

Pada penelitian yang dilakukan oleh (Nana, 2020) menyatakan bahwa dalam konsep suhu terdapat miskonsesi. Identifikasi alasan jawaban siswa berfikir (Nana, 2020):

a. Massa zat? Benda mempengaruhi besarnya suhu dan kalor, misalnya air sebagai sumber suhu, maka suhu air lebih tinggi daripada suhu benda yang berada di dalam air. 
b. Suhu campuran antara air panas dan aiar dingin adalah cenderung mendekati suhu panas, karena bersifat hangat.

c. Massa zat/benda mempengaruhi titik didih dan titik beku, misal massa es mempengaruhi titik beku.

d. Suhu dipengaruhi oleh kapasitas kalor, berarti kapasitas kalor yang besar akan mempunyai kalor yang besar sehingga suhunya tinggi.

e. Suhu dipengaruhi oleh cepatnya benda menjadi panas sehingga benda yang cepat panas (kelereng $Y$ yang kecil) akan dapat mencapai suhu yang lebih tinggi. Jawaban yang seharusnya adalah besarnya massa materi tidak mempengaruhi suhu benda, sehingga suhu pada kedua kelereng sama dengan suhu air mendidih 1000 .

Jawaban yang seharusnya adalah besarnya

massa materi tidak mempengaruhi suhu

benda, sehingga suhu pada kedua kelereng

sama dengan suhu air mendidih 1000.

2. Miskonsespsi Siswa tentang Kalor

Pada penelitian yang dilakukan (Nana, 2020) bahwa identifikasi miskonsepsi tentang kalor:

a. Suhu sama dengan kalor, sehingga suhu dianggap sebagai parameter interaksi yang dapat berpindah dari satu benda ke benda lain.

Jawaban yang sebenarnya adalah perpindahan/ aliran energi kalor diantara dua zat dapat berpindah dari suhu yang tinggi ke suhu yang rendah (Nana, 2020).

3. Miskonsespsi Siswa tentang Kalor jenis dan Kapasitas Kalor

Pada penelitian yang dilakukan (Nana, 2020) Identifikasi miskonsepsi siswa:

a. Kalor jenis dan kapasitas kalor mempengaruhi secara langsung kenaikan suhu, tetapi mempengaruhi secara terbalik penurunan suhu benda.

b. Benda yang mudah panas akan sulit dingin.

c. Kalor jenis kaca lebih kecil daripada kalor jenis besi dan kayu.

d. Kapasitas kalor dan kalor jenis sebagai parameter interaksi, yaitu kapasitas kalor dan kalor jenis di pandang sebagai sesuatu yang dapat berpindah dan satu zat / benda ke yang lain.

Jawaban yang seharusnya adalah besarnya kalor jenis dan kapasitas kalor mempengaruhi secara langsung kenaikan maupun penurunan suhu benda, sehingga benda yang mudah panas akan mudah dingin. Sedangkan kapasitas kalor dan kalor jenis merupakan ciri benda (kapasitas kalor ) yang tidak dapat berpindah (Nana, 2020).

4. Miskonsespsi Siswa tentang Perubahan Wujud

Penelitian yang dilakukan (Nana, 2020) menyatakan bahwa identifikasi miskonsepsi siswa tentang perubahan wujud:

a. Suhu air $00 \mathrm{C}$, maka suhu es 
melebur kurang dari $00 \mathrm{C}$.

b. Es ada yang berujud air dan uap.

Jawaban yang seharusnya adalah perubahan wujud terjadi pada suhu yang tetap dan kapasitas kalor mempengaruhi cepat atau lambatnya perubahan wujud suatu benda (Nana, 2020).

\section{Model POE2WE}

Model pembelajaran

Prediction, Observation, Explanation, Elaboration, Write dan Evaluation (POE2WE) dikembangkan dari model pembelajaran POEW dan model pembelajaran Fisika dengan Pendekatan Konstruktivistik. Pengembangan ini dilakukan untuk sebagai penyempurnaan kedua model sebelumnya. Model POE2WE merupakan model pembelajaran yang dikembangkan untuk mengetahui pemahaman peserta didik mengenai suatu konsep dengan pendekatan konstruktivistik. Model ini membangun pengetahuan dengan urutan proses yaitu meramalkan atau memprediksi solusi dari permasalahan, melakukan eksperimen untuk membuktikan prediksi, kemudian menjelaskan hasil eksperimen yang diperoleh secara lisan maupun tertulis, membuat contoh penerapan dalam kehidupan seharihari, menuliskan hasil diskusi dan memuat evaluasi tentang pemahaman peserta didik baik secara lisan maupun tertulis (Nana et al., 2014; Nana \& Surahman, 2019).

Model pembelajaran POE2WE dapat menjadikan peserta didik sebagai subjek di dalam pembelajaran. peserta didik secara aktif menemukan suatu konsep melalui pengamatan atau eksperimen secara langsung, bukan dari menghafal buku materi maupun penjelasan dari guru. Model ini memungkinkan peserta didik aktif dalam proses pembelajaran, memberikan kesempatan kepada peserta didik untuk mengkonstrukssi pengetahuannya, mengkomunikasikan pemikirannya dan menuliskan hasil diskusinya sehingga peserta didik lebih menguasai dan memahami konsep yang akan berdampak pada peningkatan prestasi belajar peserta didik Model ini memberikan kesempatan kepada peserta didik untuk melakukan konstruksi pengetahuan yang dimilikinya, melakukan pengamatan terhadap fenomena serta mengkomunikasikan gagasan yang dia perolah dari proses diskusi sehingga peserta didik akan lebih mudah menguasai konsep yang diajarkann (Nana, 2014, 2016; Nana et al., 2014; Nana \& Surahman, 2019).

Penggabungan tahapan-tahapan pembelajaran model POEW dan model pembelajaran Fisika dengan Pendekatan Konstruktivistik maka dapat di susun langkah-langkah pembelajaran model POE2WE secara terinci sebagai berikut: 
a) Prediction

Tahap prediction yaitu peserta didik membuat prediksi atau dugaan awal terhadap suatu permasalahan. Permasalahan yang ditemukan berasal dari pertanyaan dan gambar tentang materi yang disampaikan oleh guru yang ada di Lembar Kerja peserta didik (LKS)/buku peserta didik sebelum peserta didik membuat prediksi. Pembuatan prediksi jawaban tahap Prediction pada model POEW identik dengan fase Engagenent pada pendekatan konstruktivistik. Guru mengajukan pertanyaan yang dapat mendorong peserta didik untuk dapat membuat prediksi atau jawaban sementara dari suatu permasalahan.

b) Observation

Tahap Observation yaitu untuk membuktikan prediksi yang telah di buat oleh pesera didik. Peserta didik diajak melakukan eksperimen berkaitan dengan masalah atau persoalan yang di temukan. Selanjutnya peserta didik mengamati apa yang terjadi, kemudian peserta didik menguji kebenaran dari dugaan sementara yang telah dibuat. Tahap Observation pada model POEW identik dengan fase Exploration pada pendekatan konstruktivistik.

c) Explanation

Tahap Explanation atau menjelaskan yaitu peserta didik memberikan penjelasan terhadap hasil eksperimen yang telah dilakukan. Penjelasan dari peserta didik dilakukan melalui diskusi dengan anggota kelompok kemudian tiap kelompok mempresentasikan hasil diskusinya di depan kelas. Jika prediksi yang di buat peserta didik ternyata terjadi di dalam eksperimen, maka guru membimbing peserta didik merangkum dan memberi penjelasan untuk menguatkan hasil eksperimen yang dilakukan. Namun jika prediksi peserta didik tidak terjadi dalam eksperimen, maka guru membantu peserta didik mencari penjelasan mengapa prediksi atau dugaannya tidak benar. Tahap explanation identik dengan fase explanation pada pendekatan konstuktivistik.

d) Elaboration

Tahap elaboration yaitu peserta didik membuat contoh atau menerapkan konsep dalam kehidupan sehari-hari. Tahap elaboration di ambil dari pendekatan konstruktivistik. Tahap ini guru medorong peserta didik untuk menerapkan konsep baru dalam situasi baru sehingga peserta didik lebih memahami konsep yang di ajarkan guru. Tahap ini pengembangan dari pendekatan konstruktivistik.

e) Write

Tahap write atau menulis yaitu melakukan komunikasi secara tertulis,merefleksikan pengetahuan dan gagasan yang dimiliki peserta didik Menurut Masingilia dan Wisniowska 
(1996) dalam (Yamin \& Ansari, 2012) menulis dapat membantu peserta didik untuk mengekspresikan pengetahuan dan gagasan mereka. peserta didik menuliskan hasil diskusi dan menjawab pertanyaan yang ada pada LKS. Selain itu pada tahap write ini, peserta didik membuat kesimpulan dan laporan dari hasil eksperimen. Tahap ini merupakan pengembangan dari model TTW. f) Evaluation

Tahap Evaluation yaitu evaluasi terhadap pengetahuan, keterampilan dan perubahan proses berfikir peserta didik. Pada tahap ini peserta didik di evaluasi tentang materi gerak lurus berupa lisan maupun tulisan. Tahap ini merupakan pengembangan dari pendekatan konstruktivistik.

Penggabungan tahap-tahap model POEW dan pendekatan konstruktivistik dapat di lihat pada Tabel 1 dan 2 .

Tabel 1. Sintaks Pengembangan model POE2WE

\begin{tabular}{|c|c|c|c|}
\hline No & $\begin{array}{l}\text { Sintaks POEW } \\
\text { (Samosir, 2010) }\end{array}$ & $\begin{array}{c}\text { Sintaks model Pembelajara } \\
\text { dengan Pendekatan } \\
\text { Konstruktivistik (Duffy \& } \\
\text { Jonassen, 1992) } \\
\end{array}$ & $\begin{array}{l}\text { Model POE2WE (Nana et al., } \\
\text { 2014) }\end{array}$ \\
\hline 1 & $\begin{array}{lr}\text { (Prediction) } & \text { membuat } \\
\text { prediksi, } & \text { membuat } \\
\text { dugaan } & \end{array}$ & $\begin{array}{l}\text { (Engagement) pendahuluan } \\
\text { membuat pertanyaan menggali } \\
\text { pengetahuan awal peserta didik. }\end{array}$ & $\begin{array}{l}\text { (Prediction) } \\
\text { Membuat dugaan atau prediksi. } \\
\text { Tahap Engagement identik dengan } \\
\text { Predict pada POEW }\end{array}$ \\
\hline 2 & $\begin{array}{l}\text { (Observation) } \\
\text { Melakukan penelitian, } \\
\text { pengamatan }\end{array}$ & $\begin{array}{l}\text { (Exploration) menguji } \\
\text { prediksi, melakukan dan } \\
\text { mencatat hasil pengamatan. }\end{array}$ & $\begin{array}{l}\text { (Observation) } \\
\text { Melakukan } \\
\text { observasi/pengamatan } \\
\text { Tahap Exploration identik } \\
\text { dengan tahap observation pada } \\
\text { POEW }\end{array}$ \\
\hline 3 & $\begin{array}{l}(\text { Explanation }) \\
\text { Yaitu memberi } \\
\text { penjelasan }\end{array}$ & $\begin{array}{l}\text { (Explation) menjelaskan konsep } \\
\text { dengan kalimat mereka sendiri }\end{array}$ & $\begin{array}{l}\text { (Explanation) Menjelaskan Pada } \\
\text { tahap explanation identik dengan } \\
\text { explation pada pendekatan } \\
\text { konstruktivistik }\end{array}$ \\
\hline 4 & $\begin{array}{l}\text { (Write) } \\
\text { Membuat kesimpulan }\end{array}$ & $\begin{array}{l}\text { (Elaboration) } \\
\text { Aplikasi konsep dalam } \\
\text { kehidupan sehari-hari. }\end{array}$ & 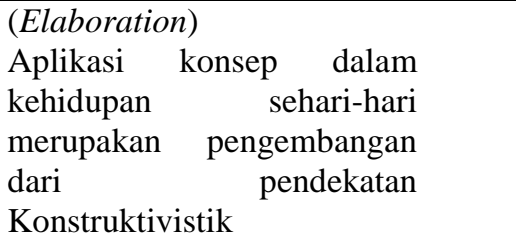 \\
\hline 5 & & $\begin{array}{l}\text { (Evaluation) } \\
\text { Evaluasi terhadap pengetahuan, } \\
\text { keterampilan dan perubahan }\end{array}$ & $\begin{array}{l}\text { (Write) } \\
\text { Menuliskan hasil diskusi sebagai } \\
\text { kesimpulan. }\end{array}$ \\
\hline
\end{tabular}




\begin{tabular}{|l|l|l|l|}
\hline & & proses berfikir peserta didik. & pengembangan dari model POEW \\
\hline & & & (Evaluation) \\
6 & & & Evaluasi terhadap efektifitas fase- \\
& & & $\begin{array}{l}\text { fase sebelumnya Merupakan } \\
\text { pengembangan dari pendekatan } \\
\text { Konstruktivistik }\end{array}$ \\
\hline
\end{tabular}

Tabel 2. Kegiatan pembelajaran Model Pembelajaran Model POE2WE

\begin{tabular}{|c|c|c|}
\hline Fase- fase & Kegiatan Guru & Kegiatan Peserta Didik \\
\hline Prediction & $\begin{array}{ll}\text { - } & \text { Menyampaikan tujuan } \\
\text { pembelajaran. } \\
\text { - } \\
\text { Mengajukan } \\
\text { pertanyaan kepada } \\
\text { siswa } \\
\text { - } & \text { Menginventarisir } \\
& \text { prediksi dan alasan } \\
\text { yang di kemukakan } \\
\text { peserta didik. }\end{array}$ & $\begin{array}{ll}\text { - } & \begin{array}{l}\text { Memperhatikan penjelasan } \\
\text { dari guru. }\end{array} \\
\text { - } & \text { Memprediksi jawaban } \\
\text { pertanyaan dari guru } \\
\text { - } \\
\begin{array}{l}\text { Mendiskusikan hasil } \\
\text { prediksinya }\end{array}\end{array}$ \\
\hline Observation & $\begin{array}{ll}\text { - } & \text { Mendorong peserta didik } \\
\text { untuk bekerja secara } \\
\text { kelompok } \\
\text { - } & \text { Membagikan LKS } \\
\text { - } & \text { Mengawasi kegiatan } \\
& \text { percobaan } \\
\text { yangdilakukan oleh } \\
\text { peserta didik }\end{array}$ & $\begin{array}{ll}\text { - } & \text { Membentuk kelompok } \\
\text { - } & \text { Melakukan percobaan } \\
\text { - } & \text { Mengumpulkan data hasil } \\
& \text { percobaan } \\
\text { - } & \text { Melakukan diskusi kelompok } \\
- & \text { Menyimpulkan hasil } \\
& \text { percobaan }\end{array}$ \\
\hline Explanation & $\begin{array}{ll}\text { - } & \text { Mendorong peserta didik } \\
\text { untuk menjelaskan hasil } \\
\text { percobaan. } \\
\text { - } & \text { Meminta peserta didik } \\
\text { pempresentasikan hasil } \\
\text { percobaannya } \\
\text { - } & \text { Mengklarifikasikan hasil } \\
\text { percobaannya } \\
\text { - } \\
\text { Menjelaskan } \\
\text { konsep/definisi baru }\end{array}$ & $\begin{array}{ll}\text { - } & \text { Mengemukakan pendapatnya } \\
\text { tentang hasil percobaan } \\
\text { - } & \text { Mengemukakan pendapatnya } \\
\text { tentang gagasan baru } \\
\text { berdasarkan hasil percobaan. } \\
\text { - } \quad \text { Menanggapi presentasi dari } \\
\text { kelompok lain. } \\
\text { - } \quad \begin{array}{l}\text { Konsep baru dari guru dapat di } \\
\text { terima }\end{array}\end{array}$ \\
\hline Elaboration & 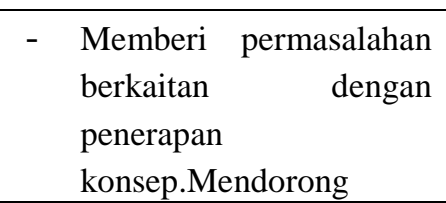 & $\begin{array}{l}\text { Menerapkan konsep baru } \\
\text { dalam situasi baru atau } \\
\text { kehidupan sehari-hari. }\end{array}$ \\
\hline
\end{tabular}




\begin{tabular}{|l|l|l|}
\hline & $\begin{array}{l}\text { peserta didik untuk } \\
\text { menerapkan konsep baru } \\
\text { dalam situasi baru. }\end{array}$ & \\
\hline Write & $-\begin{array}{l}\text { Memberi kesempatan } \\
\text { kepada peserta didik } \\
\text { untuk mencatat hasil } \\
\text { diskusi serta kesimpulan. }\end{array}$ & $\begin{array}{l}\text { Mencatat hasil penjelasan dan } \\
\text { kesimpulan dari guru dan diskusi } \\
\text { kelompok }\end{array}$ \\
\hline Evaluation & $-\begin{array}{l}\text { Mengajukan pertanyaan } \\
\text { untuk penilaian proses } \\
\text { Menilai pengetahuan } \\
\text { peserta didik } \\
\text { Memberikan balikan } \\
\text { terhadap jawaban peserta } \\
\text { didik }\end{array}$ & $-\begin{array}{l}\text { Menjawab pertanyaan } \\
\text { berdasarkan data } \\
\text { Mendemonstrasikan } \\
\text { kemampuan dalam } \\
\text { penguasaan konsep }\end{array}$ \\
& & \\
\hline
\end{tabular}

\section{Remediasi Materi Suhu dan Kalor dengan Model POE2WE}

Dengan menggunakan model POE2WE yakni Guru sebagai pemakai model dalam memasukkan hasil remediasi miskonsepsi materi suhu dan kalor ke dalam model POE2WE. Pengunaan model POE2WE dengan sintaks (Prediction) membuat dugaan atau prediksi, (Observation) melakukan observasi/pengamatan, (Explanation) menjelaskan Pada tahap explanation identik dengan explation pada pendekatan konstruktivistik, (Elaboration) aplikasi konsep dalam kehidupan sehari-hari merupakan pengembangan dari pendekatan Konstruktivistik, (Write) Menuliskan hasil diskusi sebagai kesimpulan. (Evaluation) Evaluasi terhadap efektifitas fase-fase sebelumnya (Nana et al., 2014; Nana \& Surahman, 2019).

\section{KESIMPULAN}

Dari pembahasan yang telah dipaparkan dapat ditarik kesimpulan bahwa denga model POE2WE dapat digunakan sebagai upaya remediasi miskonsepsi pada materi suhu dan kalor. Dalam pembelajaran aktivitas guru dan siswa sangat berpengaruh dalam meminimalisir terjadi miskonsepsi pada suatu materi.

\section{DAFTAR PUSTAKA}

Fitriah, Lutfiyanti. (2017). "Diagnosis Miskonsepsi Siswa Pada Materi Kalor Dengan Menggunakan Three-Tier Essay Dan OpenEnded Test Items", Berkala Ilmiah Pendidikan Fisika, Vol.5.

Nana. (2020). Penerapan Model Pembelajaran Inkuiri Terbimbing untuk Mereduksi Miskonsepsi pada konsep Gerak Lurus Siswa SMA Kelas X. Diffraction: 
Journal for Physics Education and Applied Physics, 2(1), 1-8.

Nana, Dewi R., Muhammad, A., Sajidan (2016) The Effectiveness of Scientific Approach Through Predict, Observe, Explain, Elaborate, Write and Evaluation (POE2WE) Model on the Topic of Kinetics (Rectilinear Motion) at Senior High School. The Social Sciences, 11(6), 1028-1034.

Nana. (2014). Pengembangan model POE2WE dalam pembelajaran Fisika SMA. Universitas Sebelas Maret.

Nana, Sajidan, Akhyar, M., \& Rochsatiningsih, D. (2014). The development of Predict, Observe, Explain, Elaborate, Write, and Evaluate (POE2WE) Learning Model in Physics Learning at Senior Secondary School. Journal of Education and Practice, 5(19), $56-65$

Nana. 2018. Penggunaan Pendekatan Konflik Kognitif Untuk Remediasi Miskonsepsi Pembelajaran Suhu dan Kalor. Prosiding Seminar Nasional Pendidikan Sains 2018. 8- 14
Nana, Nana \& Surahman, Endang. (2019). Pengembangan Inovasi Pembelajaran Digital Menggunakan Model Blended POE2WE di Era Revolusi Industri 4.0. Prosiding SNFA (Seminar Nasional Fisika dan Aplikasinya). 4. 82. 10.20961/prosidingsnfa.v4i0.3591 5.

Nhurzahra, dkk. (2015). "Identifikasi Miskonsepsi Fisika Pada Siswa SMAN Di Kota Palu", Jurnal Pendidikan Fisika Tadulako, Vol.3.

R. Lebdiana, D. (2015). PENGEMBANGAN PERANGKAT PEMBELAJARAN MATERI SUHU DAN KALOR BERBASIS POE (PREDICTOBSERVE-EXPLAIN) UNTUK MEREMEDIASI MISKONSEPSI SISWA. Unnes Physics Education Journal, 4(2), 2.

Wahyuningsih, Tri dkk, (2013). "Pembuatan Instrumen Tes Diagnostik Fisika SMA Kelas XI", Jurnal Pendidikan Fisika, Vol.1. 